\title{
足部の進行方向加速度を利用した遊脚後期検知アルゴリズムの開発
}

\author{
坪井 敦紀 ${ }^{* 1}$ ，伊丹 玩*2，米山 淳*3
}

\section{Algorithm for detecting late swing using only acceleration in the direction of travel of the foot}

\author{
Atsuki TSUBOI ${ }^{* 1}$, Taku ITAMI ${ }^{* 2}$ and Jun YONEYAMA ${ }^{* 3}$ \\ ${ }^{* 1}$ Department of Electrical Engineering and Electronics, Graduate School of Science and Engineering, Aoyama Gakuin University \\ 5-10-1 Fuchinobe, Chuo-ku, Sagamihara-shi, Kanagawa 252-5258, Japan \\ ${ }^{*} 2,{ }^{3}$ Department of Science and Engineering, Aoyama Gakuin University \\ 5-10-1 Fuchinobe, Chuo-ku, Sagamihara-shi, Kanagawa 252-5258, Japan
}

Received: 8 December 2021; Revised: 30 December 2021; Accepted: 12 January 2022

\begin{abstract}
If an abnormality occurs while walking and a fall occurs, elderly people with reduced muscle strength and bone density may become bedridden in the worst case due to a fracture of the neck of the femur. The purpose of this study is to develop an algorithm that detects late swing using only from the acceleration in the direction of travel for the purpose of preventing falls during walking. In this study, the late swing detection algorithm is proposed to detect from the rate of change of the traveling direction acceleration. We used motion capture system to confirm whether the discrimination late swing is detected the point between the maximum speed of the foot and the heel strike. From the results, the late swing in $88 \%$ to $98 \%$ of the gait cycle was detected using the proposed algorithm.
\end{abstract}

Keywords : Walk, Acceleration sensor, Motion capture system, Gait cycle, Bio-motion

\section{1. 緒言}

歩くことは日常生活において，最も基本的かつ重要な動作の一つである．歩行は，疲労を最小限に抑えるよう に，効率的で，転倒などの事故を防ぐように安全に行われることが理想的である（Vaughan, 2003）。歩行中に異 常が生じ，万が一転倒してしまった際，筋力や骨密度が低下している高齢者などは大腿骨頸部骨折などによって 最悪の場合寝たきりになる可能性がある（Dionyssiotis, 2012）。毎年，何百万人もの高齢者が転倒を起こしており， アメリカでは毎年 4 人に 1 人以上の高齢者が転倒していると報告されている（Bergen et al., 2014）。また，高齢者 に限らず，転倒し打ち所が悪かった場合，重大な怪我に繋がることもある。したがって，転倒は世界的に主要な公 衆衛生上の問題である.

転倒の原因としては主に内的要因，外的要因，状況的要因の 3 つがある（Rubenstein,2021）。内的要因には加齢 による変化，身体的疾患，薬による影響などがある. 加齢に伴い，筋力やバランス能力が低下することで歩行能力 が低下し，転倒するリスクが高まる。また，視力障害や認知障害などの身体的疾患があると，転倒リスクを増加 させるだけでなく，危険物や危険な状況に対する反応の仕方にも影響を及ぼす。さらに，注意力に影響を及ぼす薬 または血圧を下げる薬の使用も転倒リスクを増加させる可能性がある．外的要因には不十分な照明，小型の敷物， 滑りやすい床，通路におかれている障害物，周囲の環境に不慣れなことなどがある．状況的要因は特定の活動また は決定事項によって，転倒のリスクが高まることである．例えば，複数の作業を同時に行い注意散漫となること

No.21-00374 [DOI:10.1299/transjsme.21-00374], J-STAGE Advance Publication date : 20 January, 2022

*1 青山学院大学大学院理工学研究科理工学専攻（广252-5258＼cjkstart神奈川県相模原市中央区淵野辺 5-10-1）

*2 正員, 青山学院大学理工学部

*3 青山学院大学理工学部

E-mail of corresponding author: itami@ee.aoyama.ac.jp 
で，環境内の障害物に気づかない，トイレに急ぐなどの行為はリスクを高める，一度転倒すると，再び転倒する可 能性が 2 倍になるという報告もあり（O'Loughlin et al., 1993），過去に転倒歴があると特に注意が必要となる.し たがって，転倒を防止することはとても重要となる．外的要因である敷物や障害物などによってつまずくことで， 転倒が発生するのは足が浮いている遊脚期となる，例えば，歩行中に足の着地面に障害物などがあった場合，障 害物を避けようと足を無理やり動かすことでバランスを崩し，転倒が発生することもある（土井他, 2011）。遊脚 後期には踵接地時に生ずる衝撃力を効果的に吸収できるように関節位置を定めるとされている（Michaud, 2005）. したがって，遊脚期の中でも遊脚後期は重要な期間となる．遊脚後期を検出することで，将来的な転倒を予測す る際に遊脚後期の事象を検証することが可能となるため，転倒現象の解明に役立つことが考えられる．また，遊 脚後期を検出することにより，着地面に障害物などがあった場合，このタイミングで何らかの操作を加えることが できれば，転倒を防止することが期待できる.

これまでに歩行周期検出アルゴリズムの開発は様々な方法で行われてきた．加速度センサを背中，大腿部，下腿 部外側矢状面上, 足部の甲部分に貼付し, 加速度の変化量から歩行解析を行うもの（森田他, 2010), 加速度センサ とジャイロセンサを大腿部と足関節に貼付し, 足関節の加速度と大腿部の角速度から歩行解析を行うもの（大瀧他, 2001），6 軸 IMU センサを靴の側面に貼付し進行方向加速度と側方方向角速度から歩行解析を行うもの（Rampp et al., 2015），3 軸加速度センサを足首に貼付し，動的しきい值を使用して，歩行パターン分類するもの（Wang et al., 2012），6 軸 IMU センサを踵付近に貼付し矢状方向角速度から歩行解析を行うもの（Pérez-Ibarra et al., 2020） などがある.これらの歩行周期検出の研究では, つま先離反（TO）や踵接地（HS）などの歩行周期移行のタイミ ングの検出を行っている．転倒現象を考慮した際，歩行中の外乱や着地面の不備などがあると，踵接地の検出で は，検知タイミングが遅く，転倒する恐れがある．また，加速度や角速度など測定するデータが増えると情報が多 くなり解析が複雑になる.さらに，装着するセンサが増えると装着に時間がかかり，煩雑化する．これらの問題を 解決するため, センサ数や測定データ数を減らし, 遊脚後期を検出する必要があると考えられる.

本研究の目的は, 歩行中の転倒防止を目的とした進行方向加速度のみから踵接地の準備を行う遊脚後期を検出 するアルゴリズムの開発である. 本研究では，加速度センサのうち進行方向成分のみを利用して，遊脚後期のタイ ミングを検出する．使用センサが 1 つであることから装着にかかる時間や手間を軽減することができるほか，加 速度と角速度のデータを組み合わせるなどの解析にかかる煩雑な作業を減らすことができ，簡易なデータ分析だ けで行うことが可能となる.

本論文では，まず対象となる歩行について説明し，その後，開発した装置の説明（制御方法）について記述す る. 次に歩行周期解析の予備実験の説明と結果を述べる. 続いて, 本研究での提案手法を説明し, 提案手法を用 いた歩行実験の説明と結果を述べ，最後にまとめと今後の展望について述べる.

\section{2. 歩行周期における遊脚後期}

歩行は周期的な一連の運動の結果である（Neumann, 2012）。歩行の特徴は一連の運動単位である歩行周期から 把握できる. 図 1 に歩行周期を示す. 歩行周期中に生じる事象を説明するために歩行周期を 0 〜 $100 \%$ に細分化す ることが慣習的である. 歩行周期は足が床に着地する瞬間から始まる. この歩行周期の開始点，歩行周期の $0 \%$ は, 通常は踵から接地するので, 踵接地と呼ばれる. 同じ足が次に接地した際, 歩行周期の $100 \% て ゙$ 終了点となる. 歩

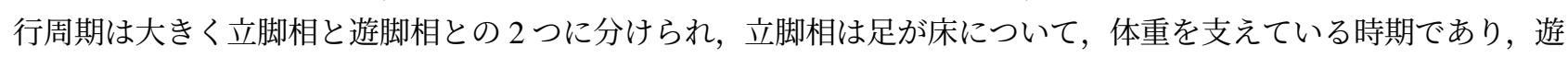
脚相は足が床から離れ, 次の接地まで前方へ振り出される時期となる. 歩行周期に占める割合は通常の歩行速度

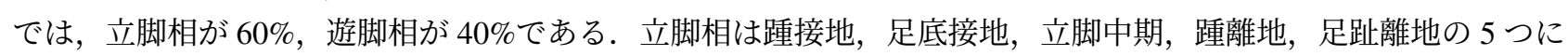
分けられ，踵接地は踵が床に着く瞬間，足底接地は足の足底面全体が床に接地時，立脚中期は重心が支持脚の上 を通過時，踵離地は踵が床から離れる瞬間，足趾離地はつま先が床から離れた瞬間となる. 踵離地から足趾離地 までを蹴り出し期ともいう。遊脚相は遊脚初期, 遊脚中期, 遊脚後期に分けられ, 遊脚初期は足趾離地から遊脚中 期までの期間，遊脚中期は遊脚側の足部が支持脚の足部を超えながら，反対側の下肢が立脚中期に入る少し前か ら立脚中期の少し後までの期間，遊脚後期は遊脚中期の終わりから踵接地までの期間となる.

遊脚後期については，著書により定義が様々である（Perry and Burnfield, 2012）（村田, 2017）(石井, 2013）。そ こで，遊脚後期は遊脚中期の終わりから踵接地までの期間であるという定義から，本研究では遊脚中期の終わりを 
足関節外果の進行方向速度が最大となる点とし，遊脚後期をこの速度が最大となる点から踵接地までと定義した.

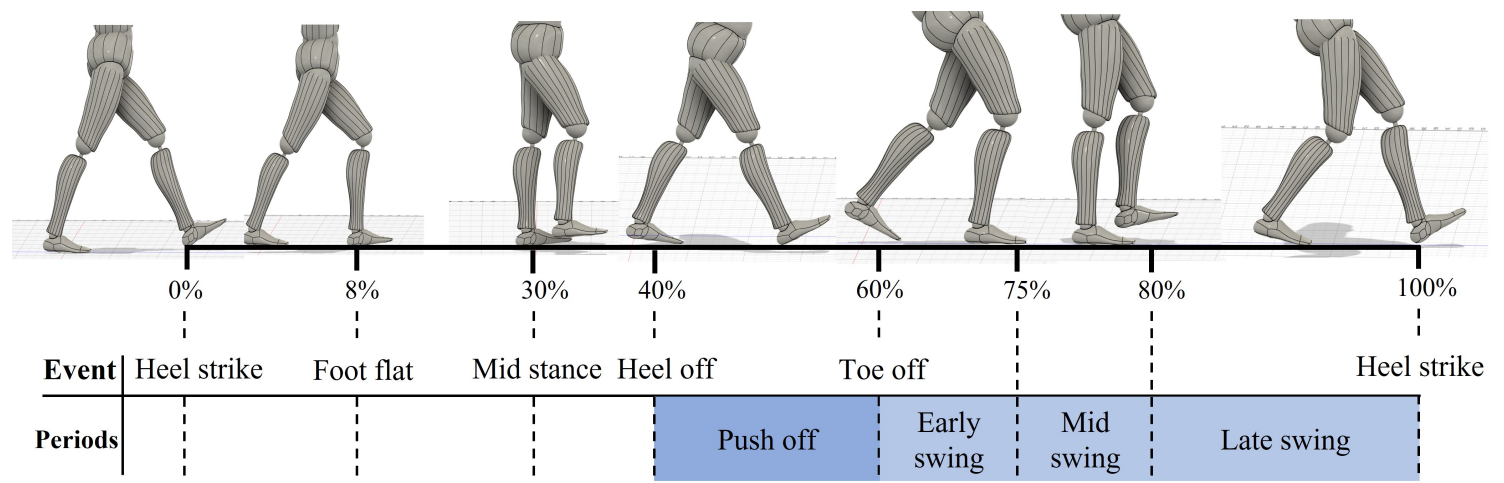

Fig. 1 Gait cycle.

\section{3. 予 備 実 験}

転倒を防止するためには，まず歩行周期を解析し，立脚期と遊脚期を判別する必要がある．はじめに歩行実験用 に開発した計測装置と予備実験方法について述べる．作製した歩行周期解析デバイスを図 2 に示す. 本デバイス には，6軸 IMU センサとして MPU-6050（InvenSense, Inc.）と圧力センサとして FSR X 402 （Interlink Electronics， Inc.）を用いた. MPU-6050 は，3 軸ジャイロスコープと 3 軸加速度計を組み合わせたもので，加速度の測定範囲 は土 $2 \mathrm{~g}$ に設定した.IMU センサの方向は，X軸に矢状面と垂直，Y 軸に足底と垂直，Z 軸に進行方向となるよう に設定した．センサはデバイス構造に固定されており，足底に対するIMU センサの位置と向きがすべての被験者 で同じ状態になるようにする。なお本研究では，トレッドミルの傾きはないので平地歩行と同様に考え，進行方 向加速度重力成分は無視している. また，IMU センサのグローバル座標系における Z 軸加速度を利用して遊脚後 期の検出が可能であったため, 本研究において進行方向加速度は IMU センサの Z 軸加速度として扱い，歩行周期 解析を行う. 加速度データおよび圧力データは，I2C 通信を介してマイクロコントローラー Arduino nanoに送信 され，同期される.MPU-6050 は右足の靴の踵の外側に取り付け，FSR X 402 は右足の靴の足裏踵付近と母子に取 り付けた. Arduino nano と MPU-6050 はブレッドボードごと靴に固定し，図 2 は見やすさのため，配線等は取り 除いてある.なお，本デバイスはノートパソコンのUSB 端子から電源供給を行った.

Arduino による測定方法を述べる. 加速度データおよび圧力センサのデータは $8 \mathrm{~ms}$ ごとに測定され（サンプリ ング周波数は $125 \mathrm{~Hz}$ ），測定開始から 5 秒間でゼロ点補正を行う.データは RCローパスフィルタを用いて補正を 行う，RCローパスフィルタの式を以下に示す.

$$
a_{r c}=\beta \times a_{r c}+(1-\beta) \times a_{\text {raw }}
$$

\section{（ただし $\beta=0.8 ， a_{r a w}$ は加速度の生データ， $a_{r c}$ は $\mathrm{rc}$ フィルタ後の加速度データ）}

続いて，予備実験について述べる．進行方向加速度を用いて歩行周期を解析する従来研究では，踵接地は加速 度がピークに達したときまたはピーク後の最小值とされており（Rampp et al., 2015, Wang et al., 2012）, 図 3 に従 来研究における遊脚中の進行方向加速度の挙動と歩行周期解析を示す.この遊脚期の進行方向加速度の推移は一 般的な推移とされている（Rampp et al., 2015, Wang et al., 2012）. 予備実験として，3 人の 20 代男性健常者で歩行 実験を行い，遊脚中の進行方向加速度の挙動を確認し，進行方向加速度データで立脚と遊脚を判別することが可 能か検証した。本実験では，図 2 の作製したデバイスを用いた。靴は同じメーカーのサイズ違いのものを使用し， 踵付近に取り付けた圧力センサの検知で LED を点灯させた. 加速度データによる立脚と遊脚を判別が可能かどう かを，踵と母子それぞれに貼付した圧力センサにより判別する．予備実験では，直立姿勢から歩行を行い，歩き 方, 歩くスピードの指定はせず，計測データは右足 2 歩目を解析した。 なお本研究にかかる実験は，本学の人を 対象とする研究倫理審査委員会の承認を得て, 実施した. (H21-030) 


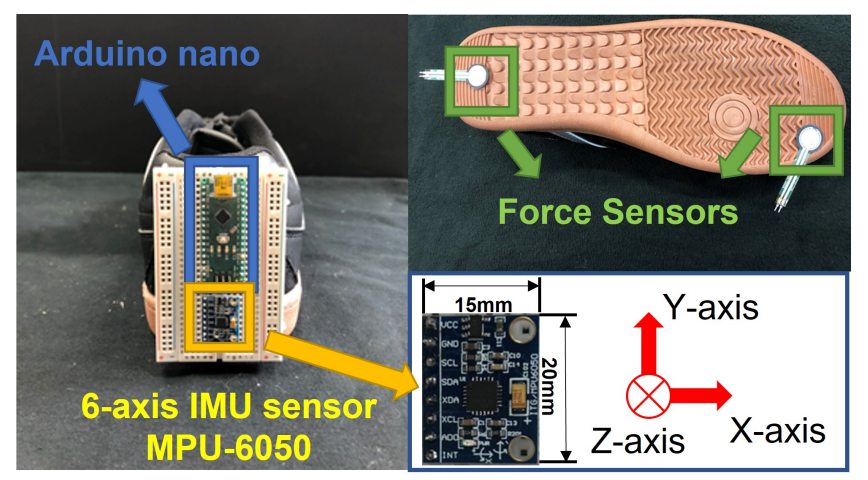

Fig. 2 Gait cycle analysis device. (Left: Device seen from the heel of the shoe, Upper right: Position of pressure sensor, Bottom right: MPU-6050)

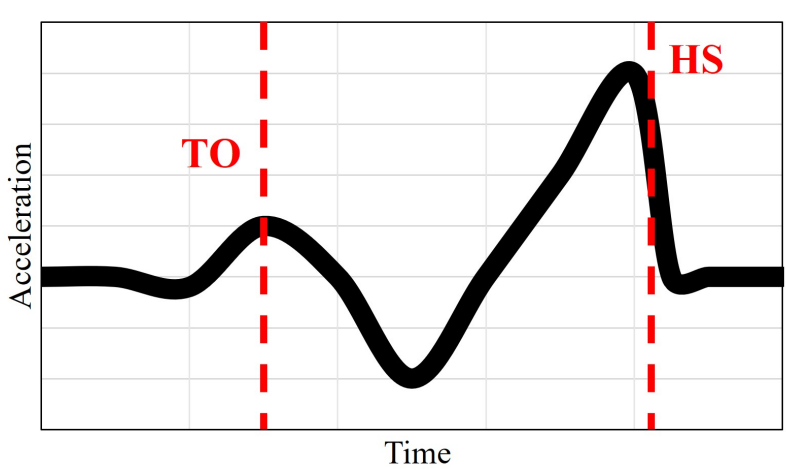

Fig. 3 Schematic diagram of the acceleration in the direction of travel during swing in previous studies.

図 4 に予備実験結果の一例を示す．図 4 は横軸に時間，縦軸に加速度と圧力センサの出力電圧を示し，青丸が進 行方向加速度，赤線が踵に貼付した圧力センサ值，黄線が母子に貼付した圧力センサ值を示している. 圧力セン サ值は，体重による圧力が加わっているときは約 $0 \mathrm{~V}$ を示し，圧力が加わっていないときは $5 \mathrm{~V}$ を示す．したがっ て，母子と踵の圧力センサ值から青い領域の中が遊脚期となることが確認できる. 立脚中は加速度の変化はなく, 遊脚中は加速度の変化が生じたため，進行方向加速度のみから立脚と遊脚の判別は可能であった．また，遊脚中 の加速度には上下に四つのピークが現れ，上に凸の二つ目のピークは上に凸の一つ目のピークより大きく，上に 凸の二つ目のピークに達した後, 踵接地が起こることが確認できた. この四つのピークは加速度の増減を表して おり，上に凸の一つ目のピークは蹴りだし期から遊脚初期の足趾離反の期間であると考えられる．前方へ踵を蹴 り上げ，足が鉛直方向最大位置に到達するまでに加速度が増加し，上に凸の一つ目のピークが現れると考えられ る. 足が鉛直方向最大位置に到達する際に進行方向加速度は減少し，鉛直方向最大位置から足をスイングさせる ことで，遊脚中期から後期にかけて再び進行方向加速度は増加し，上に凸の二つ目のピークが現れると考えられ る. 上に凸の二つ目のピーク後, 減少して踵接地が起きている. 3 人分すべてのデータでも同じ傾向が見られた.

図 4 のつま先離反は図 3 に示した上に凸の一つ目のピークではなく，ピークより前となっていることがわかる. これは圧力センサの位置によるものだと考えられる. 圧力センサを完全なつま先に取り付けると反応しないため, 今回は母子に取り付けたことによって，多少つま先離反時のずれが生じたと考えられる.しかし，本予備実験は 進行方向加速度データで立脚と遊脚を判別することが可能か検証するためのもので，より細かくつま先離反を検 出することは行わず，今回はこのずれは考慮しない，以上の結果より，従来研究と同様に進行方向加速度を用いて 立脚期と遊脚期の判別を行うことが可能であることが確認できた.

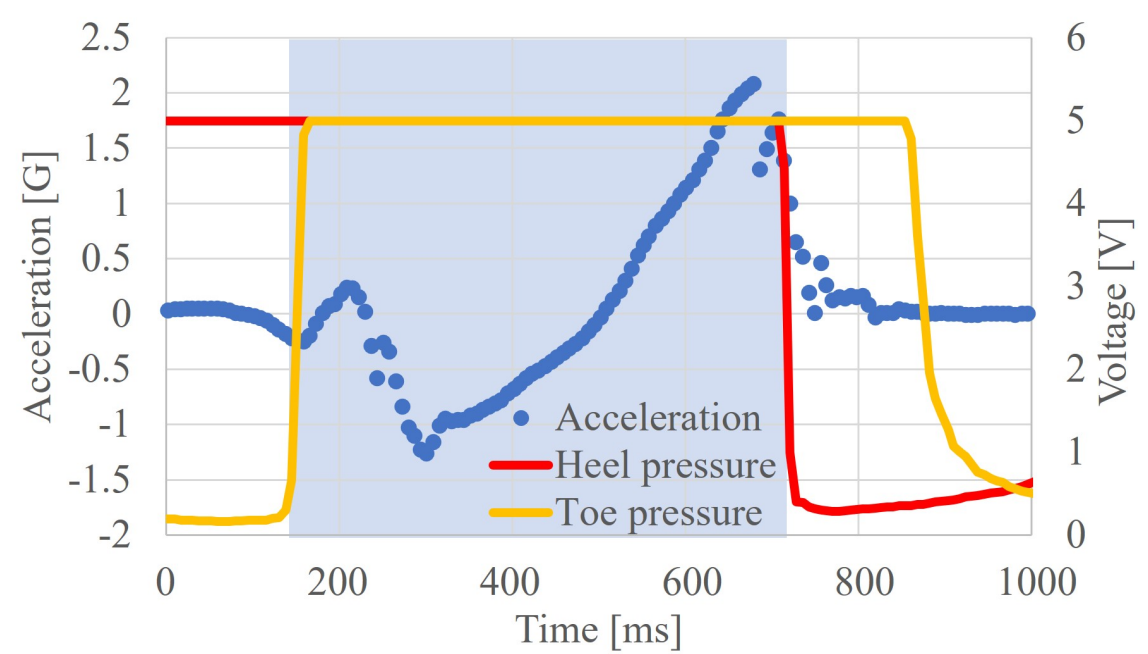

Fig. 4 Preliminary experimental results. (The light blue shaded area represents the swing leg.) 


\section{4. 提 案 手 法}

予備実験により，進行方向加速度のみから立脚と遊脚の判別を行えることが確認できた．続いて本提案となる遊 脚後期を検出可能なアルゴリズムを示す. 人間の歩行は，2つの結合された振り子の動きに例えられることがよく ある（Kuo et al., 2005）。これは，立脚中は支持脚を中心に動く倒立振子のように動作し，遊脚中は腰を中心に動 く通常の振り子のように動作するためである．また，腰を中心に動く通常の振り子は腰を支点とした振り子と膝 を支点とした振り子の二重振り子としてたとえられる（石井, 2013）。そこで本研究では，人間の歩行が振り子に 例えられることから膝を支点とした振り子に着目し，遊脚中の足の動きを振り子として捉えることで遊脚後期を 検出可能であると考えられる. 振り子において速度が最大となる点は振り子が最下点に到達したタイミングであ り，この点では加速度は 0 となる．加速度は振り子が各頂点に達したときに戻る方向に最大となる．しかし，実 際の歩行では足が摇れを繰り返すわけではないので，振り子のように振り出し，踵が接地する。したがって，実 際の歩行では足が最下点を通過し，振り上げ頂点に達したときに進行方向加速度が最大となると考えられる.

予備実験より加速度の上に凸の二つ目のピークに達した後踵接地が起こることが分かった. 二つ目のピークに 達する際に足をスイングさせるため，加速度の変化率は大きくなる．そこで本研究は，遊脚中の進行方向加速度 の変化率を検知することで，遊脚後期を検出することを提案する。

図 5 に本提案のアルゴリズムのフローチャートを示す．アルゴリズムはまず遊脚と立脚を判別する．予備実験の 結果から, 立脚中は足が動かないため, 進行方向加速度は 0 付近となる. 加速度の 5 点平均が- 0.1 から 0.1 の範囲 内に 5 点連続入ったとき，立脚と遊脚を判別する $\gamma$ 配列に 1 を格納していく．範囲外のときは 0 を格納する． -0.1 から 0.1 と範囲を設定した理由は，MPU-6050 の測定ノイズのためである. MPU-6050を動かさなくとも，加速度 センサは微量反応してしまうため，範囲を設定した．また，5点平均を使用したのは加速度の值が立脚中でも範囲 外になることがあり， 5 点平均を使うことで誤判別を防ぐためである. 5 点連続である理由も同じである. 立脚中 は加速度が 0 となることが予備実験よりわかっていたため，立脚中に遊脚と判別されることを防ぐためである， $\gamma$ 配列に 1 が 5 個連続で格納されれば立脚モード， $\gamma$ 配列に 0 が格納されれば遊脚モードと設定した. 立脚モードが 5 個連続である理由は遊脚中に立脚と判別されないようにするためである. 遊脚中の速度が最大となる点（足が最 下点を通過する点）は加速度が 0 になるので，この点で立脚と判別されないようにする. 立脚モードでは加速度の 最大值を更新していく変数 $\alpha \_\max$, 加速度の一つ目のピークの最大值を格納する変数 $\left.\beta\right\lrcorner \max$, 遊脚後期フラグ $\varepsilon$ を初期值にする．人は常に同じ歩き方を繰り返すことはなく，毎歩毎歩違った歩き方をするため，加速度の一つ目 のピークの最大值なども毎歩ごと異なってくる．したがって，毎歩ごとに立脚となった際に，変数をリセットする 必要がある. $\alpha \_\max , \beta \_\max$ の初期值が-10であるのは，加速度の一つ目のピーク值が負の值となることがあるか らである. 遊脚モードでは加速度が増加しているとき， $\alpha$ max に現在の加速度を格納していく. 加速度の一つ目 のピークを検知した際に，このときの加速度 $\alpha \_\max$ をピークの最大值を格納する変数 $\beta \_$max に格納する. 加速度 の一つ目のピークを超えると加速度は大きく減少することが測定から明らかであったため, 加速度の減少值が-0.1 を超えた際に $\beta$ max にピーク值を格納させることで，一つ目のピークを検知した．加速度の一つ目のピークを超 え，再び加速度が増加した際，現在の加速度が一つ目のピーク值 $\beta$ max より大きい，かつ加速度の変化率が最大 となったとき，遊脚後期となり， $\varepsilon$ にを代入する. 変化率は現在の加速度と一つ前の加速度の差で求めた. 変 化率が増加から減少に転じた際を変化率最大とした， $\beta$ maxに一つ目のピーク值が格納されているときかつ，遊

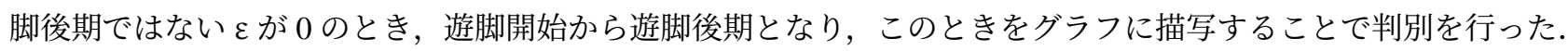




\section{Start}

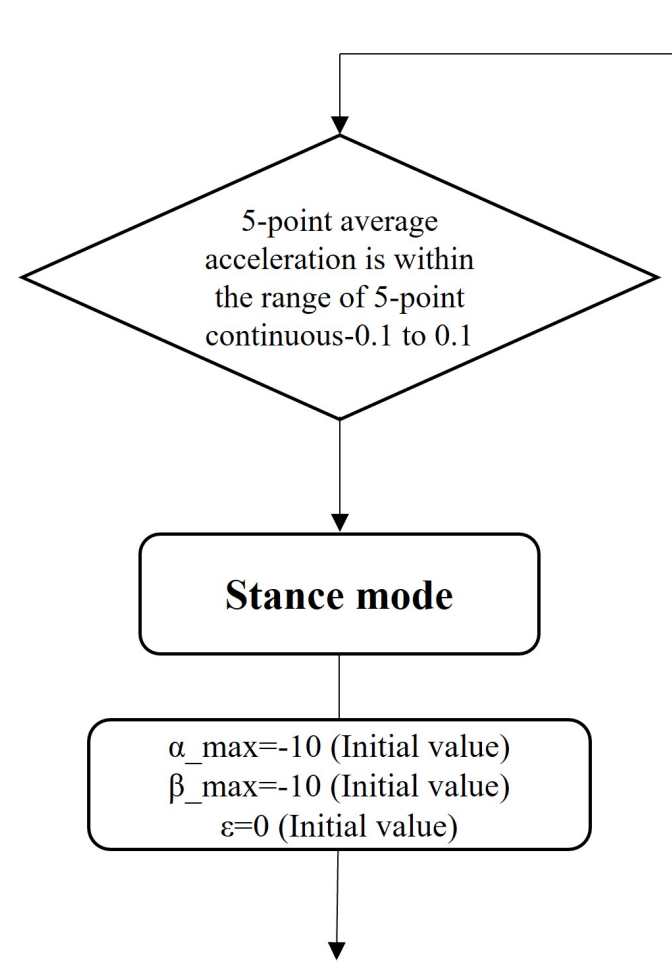

\section{Return to start}

a_max updates the maximum value of acceleration

$\beta \_$max stores the maximum value of the first peak of acceleration

$\varepsilon$ is the flag just before the heel strike

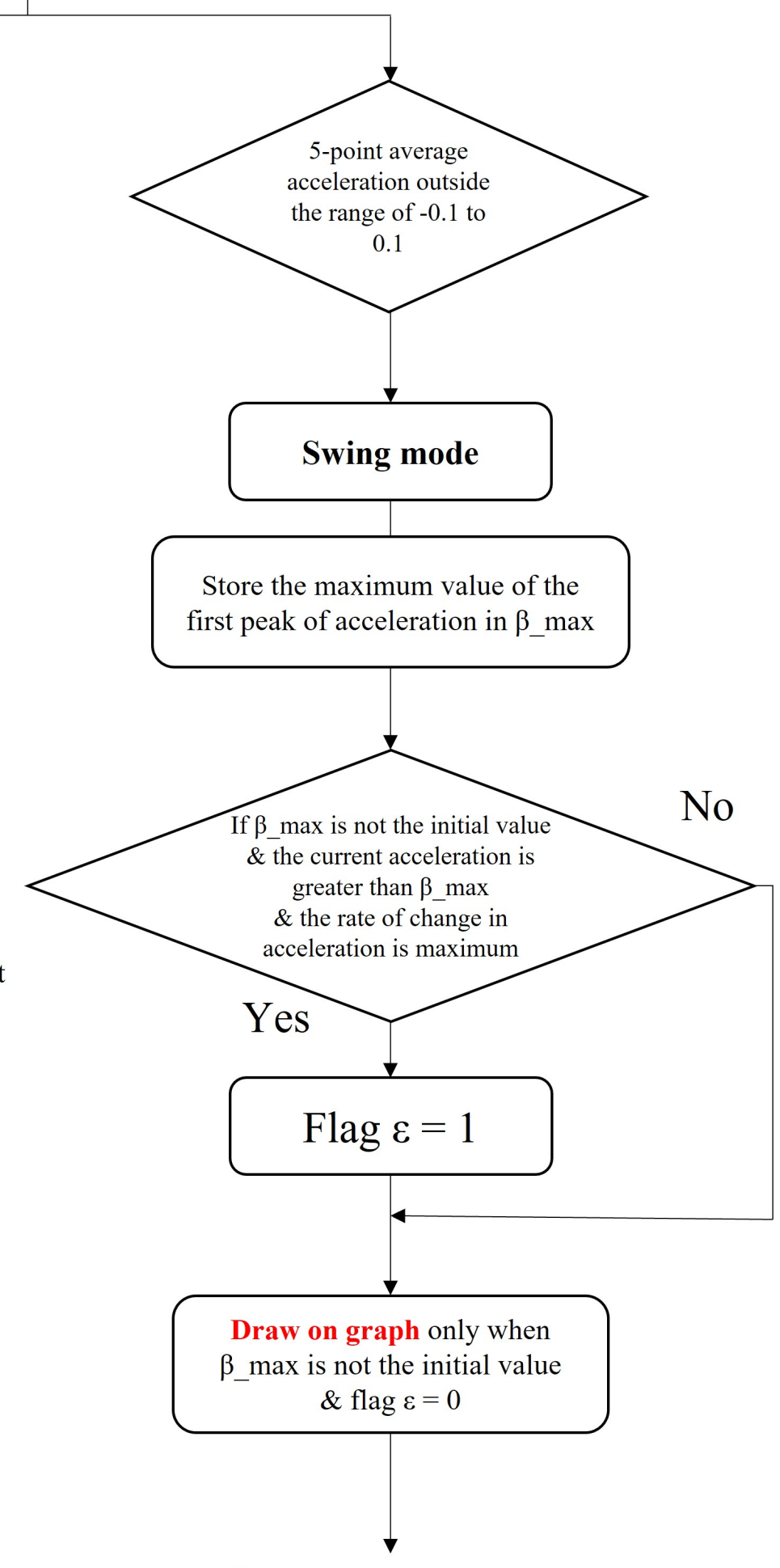

\section{Return to start}

Fig. 5 Flowchart of the algorithm of this proposal. 


\section{5. 実 験 方 法}

本提案の有効性を検証するための歩行実験について述べる．歩行実験は図 2 の作製したデバイスを用いた．図 6 にテストコースとモーションキャプチャを使用した今回の計測環境を示す. トレッドミルの歩行速度は平均歩行 速度である時速 $5 \mathrm{~km}$ とした. 被験者は 20 代男女健常者 4 人（A D ) で，直立姿勢から 30 秒間の歩行を計測した. また本実験では歩行中の下肢の挙動を確認するために，右足の足関節外果，腓骨頭，足関節外果の垂直下方向に おける靴側面，第 5 基節骨上（靴）と左足の足関節外果にマーカーを取り付け，モーションキャプチャにて計測を 行った。なお，本実験で使用したモーションキャプチャはオプティトラック・ジャパン株式会社製モーションキャ プチャシステム「OptiTrack」, 解析には同社の 3 次元動作解析ソフトウェア「Motive」を用いた. モーションキャ プチャのデータは $10 \mathrm{~ms}$ ごとに測定される（サンプリング周波数は $100 \mathrm{~Hz} ＼mathrm{~ ． ~}$

本提案アルゴリズムは進行方向加速度の変化率が最大となる点を判別する. 歩行中の加速度の変化率が最大と なる点は速度が最大となる点（足が最下点を通過する点）を通過してから踵が接地する間に存在すると考えられ るため，本実験ではモーションキャプチャを用いて，速度が最大となる点から踵が接地する間に遊脚後期の判別 が行われるかを確認し，本提案の有効性を検証した．なお，速度が最大になる点は膝を支点とした振り子より足 関節外果が膝関節の真下にあり，膝関節と足関節外果が一直線上となる点とし，踵接地は足関節外果の鉛直方向 高さから求めた.また本実験では，Arduino とモーションキャプチャという別のシステムを用いており，各データ を組み合わせるために開始点を決める必要があったため，つま先離反時を開始点とした. Arduino の開始点は母子 の圧力センサが離れた点，モーションキャプチャではつま先の進行方向座標が最小值となったときをつま先離反 とし，毎歩開始点を合わせた. Arduino とモーションキャプチャのサンプリング周波数の違いによる開始点のずれ は今回は考慮していない．また，直立姿勢時の膝関節と足関節外果の点に関して，初期補正を行った．なお，本 実験では，歩行が安定する 10 歩目からの 5 歩分の歩行データを解析し，提案アルゴリズムの有効性を検証する.

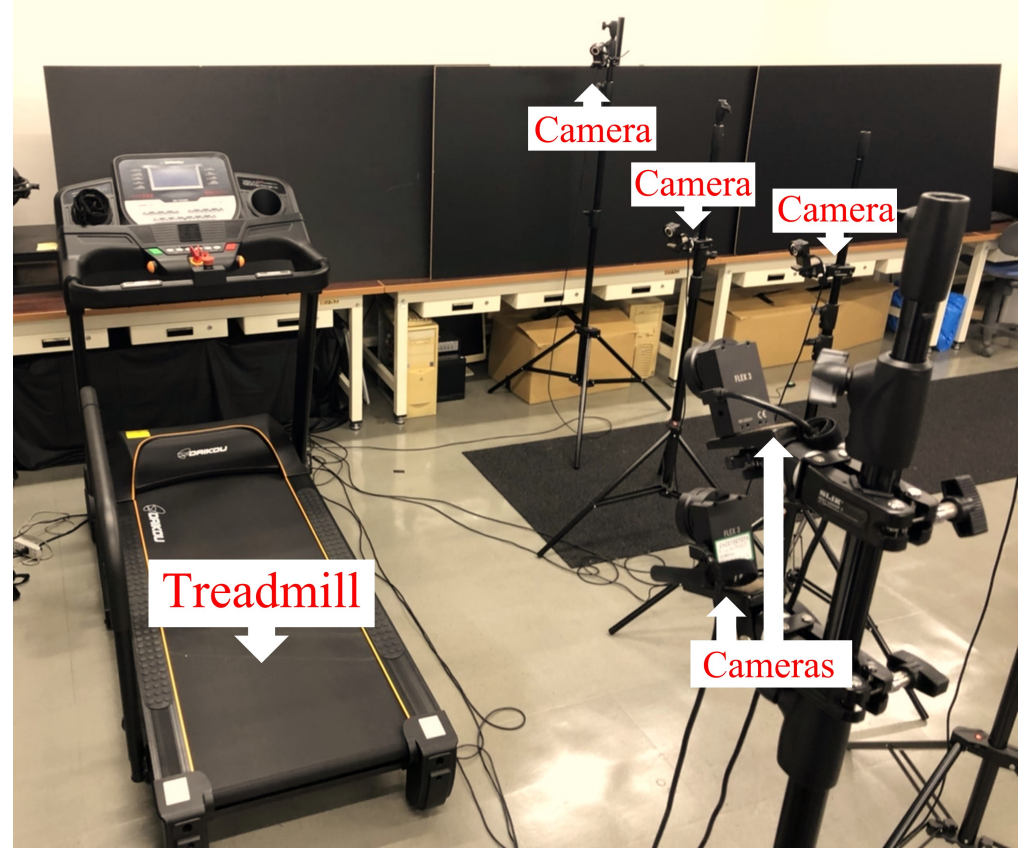

Fig. 6 Measurement environment for walking experiments. 
Tsuboi, Itami and Yoneyama, Transactions of the JSME (in Japanese), Vol.88, No.906 (2022)

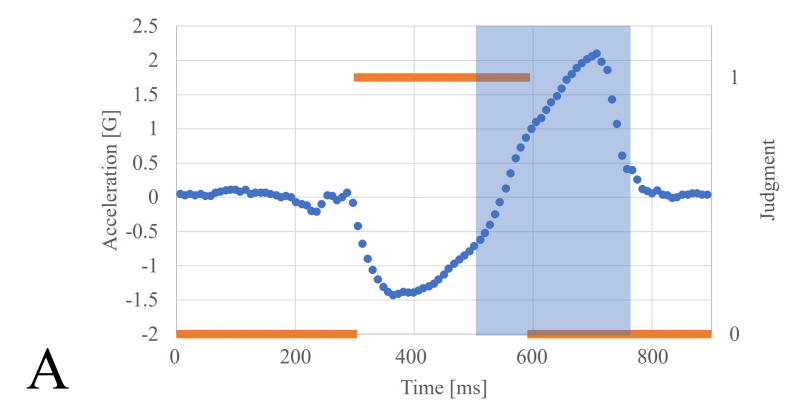

B
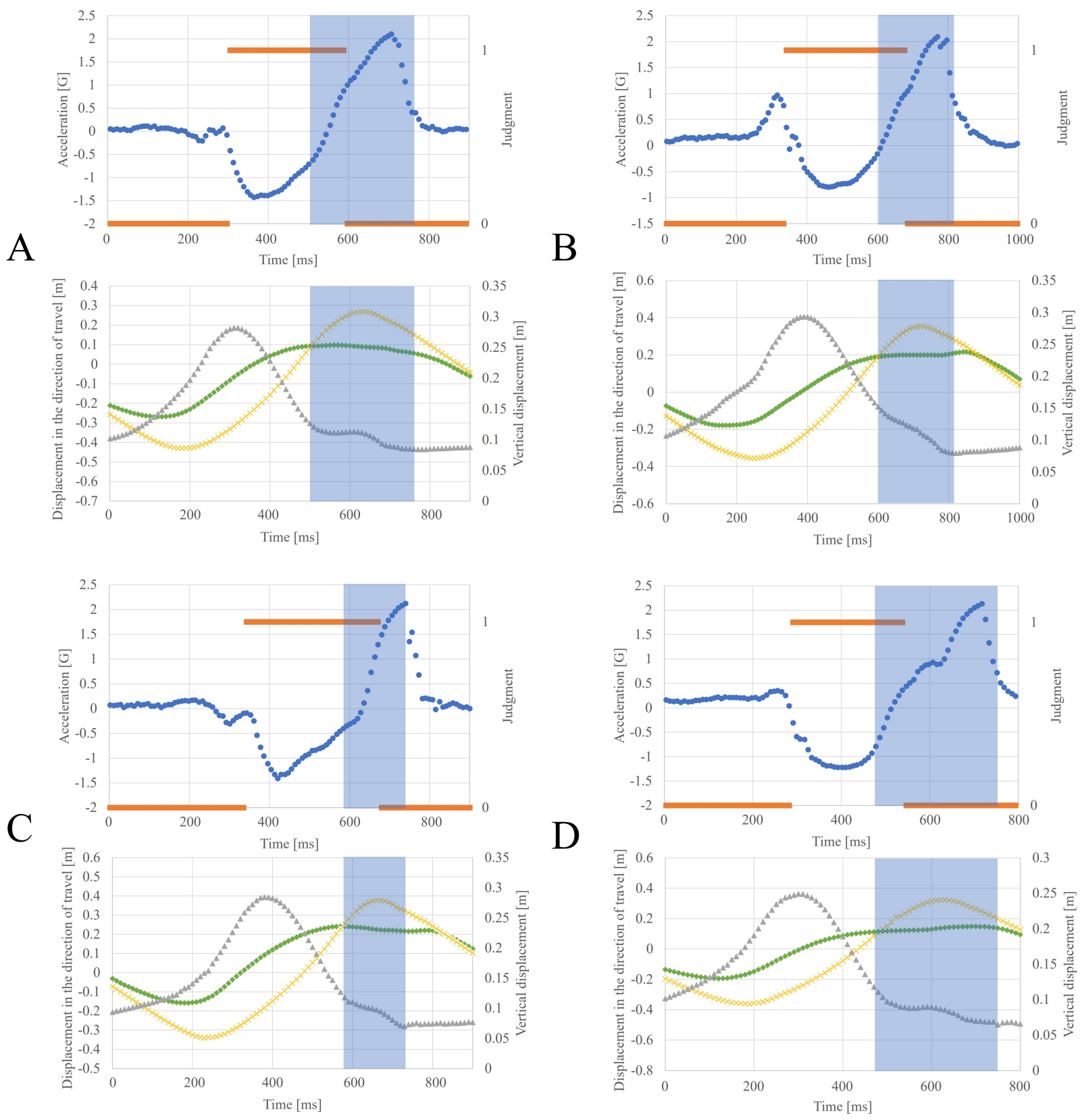

- Acceleration in the direction of travel

D
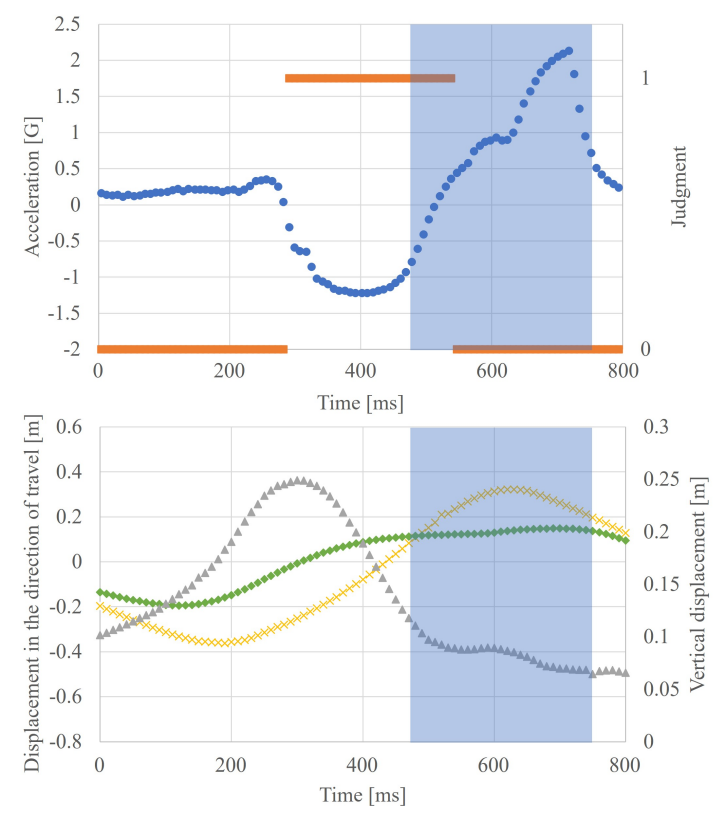

- Discrimination algorithm

$\Delta$ Vertical displacement of the ankle

- Displacement of the knee in the direction of travel

Displacement of the ankle in the direction of travel

Fig. 7 Experimental results of the 10th step for 4 subjects $(\mathrm{A} \sim \mathrm{D})$.(It can be confirmed that the end point of the discrimination algorithm is within the blue region from the mid swing to the late swing in all subjects) 
Table 1 Results of the proposed method.

\begin{tabular}{|c|c|c|c|c|c|c|}
\hline & & $\begin{array}{c}\text { Time from } \\
\text { heel strike } \\
\text { one step before } \\
\text { to the point } \\
\text { where the speed } \\
\text { is maximized } \\
{[\mathrm{ms}]}\end{array}$ & $\begin{array}{c}\text { Time from } \\
\text { heel strike } \\
\text { one step before } \\
\text { to detection } \\
\text { of late swing } \\
\text { [ms] }\end{array}$ & $\begin{array}{c}\text { Time from } \\
\text { heel strike } \\
\text { one step before } \\
\text { to the next } \\
\text { heel strike } \\
{[\mathrm{ms}]}\end{array}$ & $\begin{array}{l}\text { Percentage of } \\
\text { the point } \\
\text { where the } \\
\text { speed is } \\
\text { maximized in } \\
\text { the gait cycle } \\
{[\%]}\end{array}$ & $\begin{array}{c}\text { Percentage of } \\
\text { late swing } \\
\text { detection in } \\
\text { the gait cycle } \\
{[\%]}\end{array}$ \\
\hline \multirow{5}{*}{ A } & 10th step & 870 & 946 & 1050 & $83 \%$ & $90 \%$ \\
\hline & 11th step & 880 & 931 & 1040 & $85 \%$ & $90 \%$ \\
\hline & 12th step & 870 & 954 & 1040 & $84 \%$ & $92 \%$ \\
\hline & 13th step & 890 & 941 & 1060 & $84 \%$ & $89 \%$ \\
\hline & 14th step & 860 & 944 & 1030 & $83 \%$ & $92 \%$ \\
\hline \multirow{5}{*}{ B } & 10th step & 940 & 1017 & 1110 & $85 \%$ & $92 \%$ \\
\hline & 11th step & 940 & 1079 & 1110 & $85 \%$ & $97 \%$ \\
\hline & 12th step & 920 & 1077 & 1100 & $84 \%$ & $98 \%$ \\
\hline & 13th step & 930 & 1080 & 1110 & $84 \%$ & $97 \%$ \\
\hline & 14th step & 930 & 1035 & 1100 & $85 \%$ & $94 \%$ \\
\hline \multirow{5}{*}{$\mathrm{C}$} & 10th step & 900 & 1005 & 1030 & $87 \%$ & $98 \%$ \\
\hline & 11th step & 880 & 1002 & 1020 & $86 \%$ & $98 \%$ \\
\hline & 12th step & 890 & 993 & 1020 & $87 \%$ & $97 \%$ \\
\hline & 13th step & 890 & 996 & 1010 & $88 \%$ & $99 \%$ \\
\hline & 14th step & 900 & 1005 & 1030 & $87 \%$ & $98 \%$ \\
\hline \multirow{5}{*}{$\mathrm{D}$} & 10th step & 850 & 908 & 1050 & $81 \%$ & $86 \%$ \\
\hline & 11th step & 830 & 923 & 1050 & $79 \%$ & $88 \%$ \\
\hline & 12th step & 800 & 878 & 990 & $81 \%$ & $89 \%$ \\
\hline & 13th step & 830 & 898 & 1020 & $81 \%$ & $88 \%$ \\
\hline & 14th step & 850 & 916 & 1030 & $83 \%$ & $89 \%$ \\
\hline
\end{tabular}

\section{6. 実 験 結 果}

図 7 に対象となる 4 人分（A～D）の 10 歩目の実験結果を示す. 図 7 の上のグラフは横軸に時間，縦軸に加速度 と判別を示し，青丸が遊脚中の進行方向加速度，橙四角がアルゴリズムによる判別を表している.下のグラフは 横軸に時間，縦軸に進行方向変位と鉛直方向変位を示し，灰三角が足関節外果の鉛直方向変位，緑菱形が膝関節 の進行方向座標，黄ばつが足関節外果の進行方向座標を表している. 判別アルゴリズムが 1 を示しているときが, つま先離反から遊脚後期までを表している. 図 7 において膝関節と足関節外果の進行方向座標の交点は，膝を支 点とした振り子より足関節外果が膝関節の真下にあり, 足部の進行方向速度が最大となる点（足が最下点を通過 する点）である.また，足関節外果の鉛直方向変位が初期值になった点を踵接地としている. 速度が最大となる 点から踵接地するまでを青い領域として示している. 実験結果より，10 歩目の歩行時においては，すべての被験 者で判別アルゴリズムの終点が遊脚中期から後期である青い領域内であることが確認できた.

また，表 1 に対象 4 人（AＤ）における 10 歩目から 5 歩分の計測結果を示す. 表 1 は， 1 歩前の踵接地から速 度が最大となる点，アルゴリズムによる遊脚後期判別と次の踵接地までの時間と歩行周期における速度が最大と なる点と遊脚後期判別の割合を示す.なお，1歩前の踵接地を開始点 0 とし，この点からの時間を示す．また，1 歩前の踵接地から次の踵接地までの時間を歩行周期としている. 表 1 より速度が最大となる点から，踵接地より 早く遊脚後期判別が行われていることがわかる.また，歩行周期における遊脚後期判別の割合は 4 人それぞれ平 
均をとると，88\%から 98\%と図 1 に示した歩行周期と遊脚後期の割合に収まっていることがわかる. したがって， 今回行った 4 人分すべての歩行データにおいて，正しく遊脚後期の判別を行うことが確認できた.

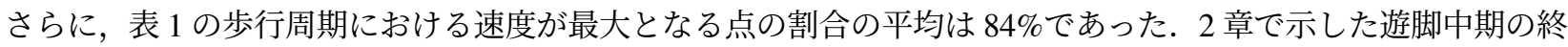
了は歩行周期の $80 \%$ となっているが，本研究では速度が最大となる点を遊脚中期の終了と定義しているため，本 提案アルゴリズムは遊脚後期の 37\%から 83\%を同定することが可能であった.

\section{7. 考察}

実験結果より進行方向加速度のみからつま先離反から遊脚後期の範囲のみを抽出し, 遊脚後期の判別が可能で あることを確認した．モーションキャプチャを用いることで，速度が最大となる点（足が最下点を通過する点）か ら踵接地が起きる間，つまり遊脚中期から遊脚後期にかけてアルゴリズムによる遊脚後期が正しく判別されてい ることが分かる．したがって，本提案の有効性を確認できた.

しかしながら，図 7 の結果より，遊脚中の足関節外果の鉛直方向変位には最大值から減少し，一定か少し増加 し，接地するパターン（A と D）と一定とはならないが減少がゆるやかになり接地するパターン（B と C）の二つ が見られた．また，A とDは遊脚後期の 41\%と 37\%を同定しているのに対し，B とCは $72 \%$ と $83 \%$ 同定してお り，割合に開きがあることが確認できた。これはそれぞれの歩き方の違いにあると考えられる．遊脚中の股関節 はつま先離反時に 20 度伸展位から屈曲していき最大 25 度まで屈曲し, 接地する. 膝関節はつま先離反時に 40 度 屈曲位から遊脚初期は最大 60 度まで屈曲し，伸展していき，接地時 5 度屈曲位まで伸展すると言われている（畠 中, 2015）。この股，膝関節の動きから，遊脚中の足関節外果の鉛直方向変位は鉛直方向最高位置から指数関数的 に低下していき接地すると予測できる．AとDはこの挙動に当てはまると考えられる．ＢとCは A と D よりは 遊脚中の足関節外果の鉛直方向変位が鉛直方向最高位置から線形的に低下していることが分かった．この違いは 歩行中の動画やモーションキャプチャからも確認できた.この歩き方の違いから遊脚後期判別の割合の違いに現 れたと考える.この指数関数的に低下するパターンと線形的に低下するパターンどちらにおいても，進行方向加 速度の変化率はおおよそ一致するため，本アルゴリズムで人それぞれ歩き方が異なるのに対し，本提案アルゴリ ズムは正しく判別されており，有効性を示すことができた.

また，本アルゴリズムでは，進行方向加速度を計測しているため，前方方向への歩行動作に関しては，長時間 においても検出可能となる. しかしながら，後方や進行方向に対して角度を持った歩行等の場合は，判定が困難 となるため，今後このような場合についても検出可能なアルゴリズムが必要となる.

さらに，トレッドミル歩行と平地歩行の違いについて考慮する必要がある. トレッドミル歩行と平地歩行の歩 行メカニズムについてはほぼ同一と報告されている（江原，山本，2008）。しかし，トレッドミル歩行には速度感 覚の違い（久保，1991）や平地歩行よりも歩幅が狭くなり，前傾姿勢を呈する（Wall and Charteris, 1980）など平 地歩行との違いも報告されている．本実験では計測環境の関係上，トレッドミル歩行で解析を行ったが，今後は 平地歩行や階段昇降など様々な環境状況に関しても解析を行う必要がある.

\section{8. 結言}

本論文では歩行周期解析に焦点を当て，進行方向加速度のみから遊脚後期を検出するアルゴリズムの提案につい て述べた. はじめに, 遊脚中の進行方向加速度の挙動を確認し, 進行方向加速度のみで立脚と遊脚を判別すること が可能か検証した． 結果より，進行方向加速度のみから立脚と遊脚を判別することは可能であった．従来研究での 結果と一致していたため, 進行方向加速度のみを使った歩行周期解析は有効であった. しかし，現状の歩行周期解 析はつま先離反や踵接地などの歩行周期移行のタイミングの検出を行っている. 歩行中の外乱や着地面の不整な どがあった場合，踵接地の検出では遅く，転倒してしまう可能性がある．そこで本研究では，遊脚中期から遊脚後 期に着目し, 遊脚中の進行方向加速度の変化率を検知することで遊脚後期を検出可能なアルゴリズムを提案した.

本提案アルゴリズムの有効性を示すために，4名の被験者による歩行実験を実施した．実験はトレッドミルを 用い，平均歩行速度である時速 $5 \mathrm{~km}$ で歩行を行った．遊脚後期が正しく判別されているかを検証するためにモー ションキャプチャを用いて，速度が最大となる点（足が最下点を通過する点）から踵が接地する間に遊脚後期の 判別が行われるかを確認した．結果より，人それぞれ歩き方が異なるのに対し，本提案アルゴリズムは正しく判 
別されており，有効性を示すことができた．また，本提案アルゴリズムの遊脚後期検出は歩行周期における $88 \%$ から 98\%を同定し，遊脚後期の 37\%から 83\%を同定することが可能であった.

今後の展望としては，高齢者や下肢機能障害者など被験者を増やし，様々な人にも適用できるのかを検証する. さらには，本研究のアルゴリズムを応用していくことで，転倒防止装置などの開発にも期待できる.

謝 辞

この研究は，2020 年度スズキ財団の助成金交付により研究が遂行されたものです。この場を借りて深く御礼申 し上げます。

\section{文献}

Bergen, G., Stevens, M.R. and Burns, E.R., Falls and Fall Injuries Among Adults Aged $\geq 65$ Years - United States (2014). MMWR Morb Mortal Wkly Rep 2016;65:993-998. DOI: http://dx.doi.org/10.15585/mmwr.mm6537a2.

Dionyssiotis, Y., Analyzing the problem of falls among older people, International Journal of General Medicine (2012), 5:805-13. doi: 10.2147/IJGM.S32651. Epub 2012 Sep 28.

土井有羽子, 上野昌江, 和泉京子, The Connection between Circumstances Regarding Falls among the Elderly Woman

Who Reside in Their Own Homes and Housing Environment, 日本地域看護学会誌, Vol.13, No.2 (2011), pp.46-53.

江原義弘，山本澄子, 臨床歩行計測入門, 医歯薬出版株式会社 (2008).

畠中泰彦, PT・OT ビジュアルテキスト姿勢・動作・歩行分析 第 1 版, 羊土社 (2015).

石井慎一郎, 動作分析 臨床活用講座 バイオメカニクスに基づく臨床推論の実践, 株式会社メジカルビュー社 (2013).

久保晃, トレッドミル歩行速度の知覚について, 運動生理 6(1) (1991), pp.33-38.

Kuo, A.D., Donelan, J.M., Ruina A., Energetic consequences of walking like an inverted pendulum: step-to-step transitions, Exerc Sport Sci Rev. (2005) Apr;33(2):88-97. doi: 10.1097/00003677-200504000-00006.

Michaud, T.C., 臨床足装具学 生体工学的アプローチ, 医歯薬出版株式会社 (2005).

森田祐也, 岡本淳, 川村和也, 関雅俊, Sessa, S., Zecca, M., Lin, Z., 石井裕之, 高杉紳一郎, 高西淳夫, 藤江正克, Gait analysis system of presumption of method to estimate right and left separated ground reaction force using acceleration sensor, (社) 日本機械学会 [No.10-52] 生活生命支援医療福祉工学系学会連合大会 2010 講演論文 集〔2010.9.18-20, 豊中〕

村田伸, 歩行分析 シート式足圧センサーを用いた歩行分析に関する研究, 学術研究出版 (2017).

Neumann, D.A., KINESIOLOGY of the MUSCULOSKELETAL SYSTEM Foundations for Rehabilitation Third Edition, 医歯薬出版株式会社 (2018).

大瀧保明, 佐川貢一, 猪岡光, A method for the Long-Term Gait Assessment Utilizing Accelerometers and Gyroscopes, 日本機械学会論文集 C 編, Vol.67, No.655 (2001).

O'Loughlin, J.L., Robitaille, Y., Boivin, J. and Suissa, S., Incidence of and risk factors for falls and injurious falls among the community-dwelling elderly, American journal of epidemiology, Vol.137, No.3 (1993), pp.342-354.

Pérez-Ibarra, J.C., Siqueira, A.A.G., Member, IEEE, and Krebs, H.I., Fellow, IEEE, Real-Time Identification of Gait Events in Impaired Subjects Using a Single-IMU Foot-Mounted Device, IEEE SENSORS JOURNAL, Vol.20, No.5, MARCH 1 (2020).

Perry, J. and Burnfield, J.M., GAIT ANALYSIS Normal and Pathological Function Second Edition, 医歯薬出版株式会 社 (2012).

Rampp, A., Barth, J., Sch"ulein, S., Ga $\beta$ mann, K., Klucken, J. and Eskofier, B.M., Member, IEEE, Inertial SensorBased Stride Parameter Calculation From Gait Sequences in Geriatric Patients, IEEE TRANSACTIONS ON BIOMEDICAL ENGINEERING, Vol.62, No. 4, APRIL (2015).

Rubenstein, L.Z., MSD マニュアルプロフェッショナル版, (online), available from〈https://www.msdmanuals.com/en$\mathrm{jp} /$ professional〉, (参照日 2021 年 8 月 17 日).

Vaughan, C.L., Theories of bipedal walking: an odyssey, J Biomech 36 (2003) pp.513-523. 
Wang, J., Member, IEEE, Lin, C., Yang, Y.C. and Ho, Y., Walking Pattern Classification and Walking Distance Estimation Algorithms Using Gait Phase Information, IEEE TRANSACTIONS ON BIOMEDICAL ENGINEERING, Vol.59, No.10, OCTOBER (2012).

Wall, J.C. and Charteris, J., The process of habituation to treadmill walking at different velocities, Ergonomics (1980) May;23(5):425-35. doi: 10.1080/00140138008924758.

\section{References}

Bergen, G., Stevens, M.R. and Burns, E.R., Falls and Fall Injuries Among Adults Aged $\geq 65$ Years - United States (2014). MMWR Morb Mortal Wkly Rep 2016;65:993-998. DOI: http://dx.doi.org/10.15585/mmwr.mm6537a2.

Dionyssiotis, Y., Analyzing the problem of falls among older people, International Journal of General Medicine (2012), 5:805-13. doi: 10.2147/IJGM.S32651. Epub 2012 Sep 28.

Doi, Y., Ueno, M. and Izumi, K., The Connection between Circumstances Regarding Falls among the Elderly Woman Who Reside in Their Own Homes and Housing Environment, Journal of Japan Academy of Community Health Nursing, Vol.13, No.2 (2011), pp.46-53.

Ehara, Y. and Yamamoto, S., Introduction to Clinical Gait Measuring, Ishiyaku Publishers, Inc. (2008) (in Japanese).

Hatanaka, Y., PHYSICAL THERAPY OCCUPATIONAL THERAPY VISUAL TEXT, YODOSHA (2015) (in Japanese).

Ishii, S., Clinical Practice of Motion Analysis with Clinical Reasoning Basede on Biomechanics, Medical View Co., Ltd. (2013) (in Japanese).

Kubo, A., Perception of Walking Speed on a Treadmill, J. Exerc. Physiol. 6(1) (1991), pp.33-38 (in Japanese).

Kuo, A.D., Donelan, J.M., Ruina A., Energetic consequences of walking like an inverted pendulum: step-to-step transitions, Exerc Sport Sci Rev. (2005) Apr;33(2):88-97. doi: 10.1097/00003677-200504000-00006.

Michaud, T.C., FOOT ORTHOSES and Other Forms of Conservative Foot Care, Ishiyaku Publishers, Inc. (2005) (in Japanese).

Morita, Y., Okamoto, J., Kawamura, K., Seki, M., Sessa, S., Zecca, M., Lin, Z., Ishii, H., Takasugi, S., Takanishi, A. and Fujie, M., Gait analysis system of presumption of method to estimate right and left separated ground reaction force using acceleration sensor, Japan Society of Mechanical Engineers [No.10-52] WWLS 2010 (2010), pp. 489-491 (in Japanese).

Murata, S., Gait analysis Research on gait analysis using a seat-type foot pressure sensor, Academic Research Publication (2017) (in Japanese).

Neumann, D.A., KINESIOLOGY of the MUSCULOSKELETAL SYSTEM Foundations for Rehabilitation Third Edition, Elsevier Japan KK, Ishiyaku Publishers, Inc. (2018) (in Japanese).

Ohtaki, Y., Sagawa, K. and Inooka,H., A method for the Long-Term Gait Assessment Utilizing Accelerometers and Gyroscopes, Transactions of the Japan Society of Mechanical Engineers, Series C, Vol.67, No.655 (2001), pp.192198 (in Japanese).

O’Loughlin, J.L., Robitaille, Y., Boivin, J. and Suissa, S., Incidence of and risk factors for falls and injurious falls among the community-dwelling elderly, American journal of epidemiology, Vol.137, No.3 (1993), pp.342-354.

Pérez-Ibarra, J.C., Siqueira, A.A.G., Member, IEEE, and Krebs, H.I., Fellow, IEEE, Real-Time Identification of Gait Events in Impaired Subjects Using a Single-IMU Foot-Mounted Device, IEEE SENSORS JOURNAL, Vol.20, No.5, MARCH 1 (2020).

Perry, J. and Burnfield, J.M., GAIT ANALYSIS Normal and Pathological Function Second Edition, Ishiyaku Publishers, Inc. (2012) (in Japanese).

Rampp, A., Barth, J., Sch”ulein, S., Gaßmann, K., Klucken, J. and Eskofier, B., Member, IEEE, Inertial SensorBased Stride Parameter Calculation From Gait Sequences in Geriatric Patients, IEEE TRANSACTIONS ON BIOMEDICAL ENGINEERING, Vol.62, No. 4, APRIL (2015).

Rubenstein, L.Z., MSD MANUAL Professional Version, available from 〈https://www.msdmanuals.com/enjp/professional>, (accessed on 17 August, 2021).

Vaughan, C.L., Theories of bipedal walking: an odyssey, J Biomech 36 (2003), pp.513-523. 
Wang, J., Member, IEEE, Lin, C., Yang, Y.C. and Ho, Y., Walking Pattern Classification and Walking Distance Estimation Algorithms Using Gait Phase Information, IEEE TRANSACTIONS ON BIOMEDICAL ENGINEERING, Vol.59, No.10, OCTOBER (2012).

Wall, J.C. and Charteris, J., The process of habituation to treadmill walking at different velocities, Ergonomics (1980) May;23(5):425-35. doi: 10.1080/00140138008924758. 